\title{
The Relationship Between Risk Management Practices and Financial Performance of Credit Unions in Ghana
}

\author{
Joseph Kwasi Agyemang ${ }^{1 *} \quad$ Collins Kankam-Kwarteng ${ }^{2} \quad$ Frank Oppong Kyekyeku ${ }^{3}$ \\ Bonvas Makori Mogunde ${ }^{4}$ \\ 1. Department of Accounting and Finance, Faculty of Commerce, University of Eswatini, Eswatini \\ 2. Department of Marketing, Faculty of Business and Management, Kumasi Technical University, Ghana \\ 3. Finance Manager, Kumawuman Rural Bank Limited, Ghana \\ 4. Department of Accounting and Finance, Faculty of Commerce, University of Eswatini, Eswatini
}

\begin{abstract}
The study investigated the influence of risk management practices on the financial performance of some selected credit unions in Kumasi metropolis; therefore a descriptive qualitative design was adopted where both primary data and secondary data were used. A total number of One Hundred (100) respondents were selected using the purposive sampling technique. A questionnaire was used as data collection instrument. Statistical Package for Social Science (SPSS) was used to analyse the data gathered from the respondents. The analysis revealed that all the risk management practices variables such as risk management environment, policies and procedures, risk measure, risk mitigation, risk monitoring and internal control have strong positive relationship with return on asset (ROA) and return on equity (ROE). Also the study revealed that the higher the return on asset (ROA), the better will be the risk measurement practices and risk monitoring practices in the credit unions. With regard to return on equity (ROE), credit unions that have higher return on equity (ROE) tend to practice better internal control practices. It is concluded that, there is strong statistically significant relationships between risk management practices and financial performance. The study recommends that senior management should recognize that the future is inherently uncertain and that its endless possibilities are too complex for anyone to predict with great accuracy. Instead of maintaining the illusion that the future can be fully understood or controlled, senior management should show courage and honesty when updating key stakeholders based on the latest forecasts.
\end{abstract}

Keywords: Risk Management, Return on Assets, Return on Equity, Financial Performance

DOI: $10.7176 / \mathrm{RJFA} / 11-17-08$

Publication date:October $31^{\text {st }} 2020$

\subsection{Background of the study}

One key activity in the financial sector globally is the advancement of credit to deserving clients and deficit units of the economy. In as much as providing credit remains the main revenue generating activity of most financial institutions, it poses a huge risk to both the lender and the borrower. Banks are subjected to a wide array of risks in the course of their operations and generally banking risks fall into three categories: financial, operational, and environmental risks (Greuning \& Bratanovic, 2009). As emphasized by Onang'o et al., (2017), where a trading partner refuses to fulfill a promise to pay back a loan on due date, it goes a long way to affect the smooth functioning of a bank's business. They further indicate that a bank with a high credit risk has high bankruptcy risk which may eventually put depositors in danger.

A thorough scan of available financial literature depicts that, at least the issue of risk management practices has been the subject of great interest in the past decade. The exposure to credit risk continues to be the leading source of problems in most financial and banking firms and as a result needs to be managed. Michael et al., (2011) notes that Credit risk is a core pillar for the viability of banks and credit institutions. Scholars have argued that banks performance and profitability are significantly affected due to need to allocate more resources to mitigate these risks. In particular, the greater risk mitigation requirements call for adequate capital and reserves, appropriate pricing and control of risks, strong rules and practices for governance, disclosure, accounting, and auditing rules, and suitable infrastructure that could facilitate liquidity management (Sundararajan \& Errico, 2002).

In relating risk management practices and performance, several studies have documented negative effects of increased capital requirements on bank performance. This includes that of Brinkmann and Horvitz (1995) which documents a significant decline in bank loan supply by the US banks due to need to comply with the Basle I requirements. Similarly, Furlong (1992) shows significant decline in the US bank lending due to the imposition of capital regulations. However, Peek and Rosengren (1995) and Berger and Gregory (1994) find contradictory findings. Despite the well-established literature on the conventional banks, studies on the relationship between risk management practices and the Islamic banks performance, to our knowledge, is lacking at the moment.

This study aims to fill the gap in the literature by focusing on the risk management practices of the selected credit unions and linking the practices with the financial performance of those credit unions. The study focuses on Kumasi because of the banking experience industry in that region thus allowing complete data collection and reliable analysis. The study hopes to contribute in terms of recommending strategies to strengthen the risk 
management practices of the selected credit unions so as to increase the overall competitiveness in the banking industry.

\subsection{Objectives of the Study}

Generally, this study sought to establish the relationship between risk management practices and financial performance amongst credit unions in the Ashanti Region of Ghana. The specific objectives were:

i. To establish the relationship between risk management environment, policies and procedures and financial performance

ii. To establish the relationship between risk measurement and financial performance

iii. To establish the relationship between risk mitigation and financial performance

iv. To establish the relationship between risk monitoring and financial performance

v. To establish the relationship between internal control and financial performance

\subsection{Concept of Risk Management}

Risk management framework is important for banks. The risk management strategy must be integrated with its overall corporate strategies (Froot \& Stein, 1994). In conjunction with the underlying frameworks, basic risk management process that is generally accepted is the practice of identifying, analysing, measuring, and defining the desired risk level through risk control and risk transfer. BCBS (2001) defines financial risk management as a sequence of four (4) processes: (1) the identification of events into one or more broad categories of market, credit, operational and other risks into specific sub-categories; (2) the assessment of risks using data and risk model; (3) the monitoring and reporting of the risk assessments on a timely basis; and (4) the control of these risks by senior management. BCBS (2006), on risk management processes, require supervisors to be satisfied that the banks and their banking groups have in place a comprehensive risk management process. This would include the Board and senior management to identify, evaluate, monitor and control or mitigate all material risks and to assess their overall capital adequacy in relation to their risk profile. In addition, as suggested by Al-Tamimi (2002), in managing risk, commercial banks can follow comprehensive risk management process which includes eight (8) steps: exposure identification; data gathering and risk quantification; management objectives; product and control guidelines; risk management evaluation; strategy development; implementation; and performance evaluation (e.g. Baldoni, 1998; and Harrington \& Niehaus, 1999).

In establishing the relationship between risk management practices and financial performance, there is a need for more profound comprehension on the estimation of risk management practices. The utilization of poll overview is exceptionally reasonable as banks ordinarily uncover negligible subtleties on their risk management strategies in their yearly reports (Tufano, 1996). Thus, polls reviews are utilized to gauge risk management practices of banks by giving a score to their practices. The poll is adjusted from Khan and Ahmed (2001) and Mohd Ariffin et al. (2009). To quantify the risk management practices, five significant segments in reference to Basel Committee on Banking Supervision (1999 \& 2001) and Bank Negara Malaysia (2001) are utilized. The five segments are Risk Management Environment, Policies and Procedures, Risk Measurement, Risk Mitigation, Risk Monitoring and Internal Control. All are then link with the mean of return on asset (ROA) and return on equity (ROE)

\subsection{Risk Management Practices}

The economic crisis generated questions regarding the effectiveness of risk management practices (RMPs) applied by banks and bad the crisis happened because of the week risk management. Academics and practitioners agreed that efficient and effective risk management is accepted and considered as a main factor of bank management. The Basel Committee introduced the Basel I Accords, then formulated the Basel II Accords and recently formulated the Basel III in order to deal with this problem. In addition that risk management is considered to be one of the most important determinants of returns of banks' stocks. Mokni and Rachdi (2012) defined risk management as a core activity of every financial institution that involves identification, measurement, monitoring and controlling risks. Hence, it is imperative on the risk manager to have a comprehensive understanding of the risk and the measurement of the risk exposure in order to effectively carry the tasks entrusted on him. (Al-Mazrooei \& Al Tamimi, 2007) showed that monitoring and screening is important to be done by auditors and managers through investigations and analysing the financial system. The study showed important variables affecting risk management practices such as Risk Management Environment, Policies and Procedures, Risk Measurement, Risk Mitigation, Risk Monitoring and Internal Control.

\subsubsection{Risk Management Environment, Policies and Procedures}

Risk management environment, policies and procedures involves determining the acceptable level of exposure to risk, which enables the achievement of organization whilst achieving a balance between the level of risk exposure and the cost of mitigating actions. Risk will be recognized, surveyed, oversaw and detailed by dependable officials as it will evaluated with reference to key targets and needs. One of the key targets of undertaking a risk appraisal is the differential of minor and adequate operational hazard from major key and operational dangers that requires 
thought about evaluation and dynamic administration, and to give information that aids both the assessment and treatment of dangers. Risk appraisal requires the thought of the wellsprings of risk, their probability and potential results with regards to the controlling nature. Controls can influence the probability or likelihood of an occasion to happening to the degree of the outcomes or the effect. To have the option to sufficiently survey risk, the quality and shortcoming of the controls additionally should be evaluated.

\subsubsection{Risk Measurement}

The proliferation of subsidiary instruments has been joined by expanded exchanging of money instruments and protections and an expansion of various financing openings, and has been correspondent with development in outside exchange and expanding universal financial linkages among organizations. Because of these patterns, numerous organizations have portfolios which incorporate enormous quantities of money and subsidiary instruments. Because of the sheer numbers and intricacy (of a few) of these money and subsidiary instruments, the sizes of the dangers in organizations' portfolios regularly are not self-evident. This has prompted an interest for portfolio level quantitative proportions of market hazard, for example, "esteem in danger". The adaptability of subordinate instruments and the straightforwardness with which both money and subsidiary instruments can be exchanged and retraded to modify organizations' risks also has made an interest for a portfolio level synopsis risk measure that can be accounted for to the ranking directors accused of the oversight of risk the board and exchanging activities. Incentive in danger is the main such rundown portfolio risk measure. The idea and utilization of significant worth in danger is moderately later. Incentive in danger was first utilized by major monetary firms in the late 1980's to quantify the dangers of their exchanging portfolios. Since that time span, the utilization of significant worth in danger has detonated, with J.P. Morgan's endeavor to build up a market standard through its arrival of its Risk Metrics framework in 1994 (Morgan 1994) giving an enormous catalyst to the growth. Value in danger is presently generally utilized by littler money related organizations, non-budgetary partnerships, and institutional investors. Even controllers additionally have turned out to be keen on an incentive in danger. For instance, the Basle Committee on Banking Supervision (Basle Committee 1996) licenses banks to ascertain their capital necessities for market risk utilizing their own exclusive incentive in danger models, while the Securities and Exchange Commission (SEC 1997) requires that U.S. organizations uncover quantitative proportions of market risk, with incentive in risk recorded as one of three conceivable market risk divulgence measures.

\subsubsection{Risk Mitigation}

Risk Mitigation allows managers to balance the operational and economic costs of protective measures and achieve gains in mission capability by protecting the agency systems and data that support their missions. The end of all risk is normally unrealistic or near incomprehensible. In this manner, it is the obligation of the board to utilize the most financially savvy approach and actualize the most fitting controls to diminish mission risk to a worthy level, with insignificant unfavorable effect on the office's assets and mission. The elimination of all risk is usually impractical or close to impossible. Therefore, it is the responsibility of management to use the most cost effective approach and implement the most appropriate controls to decrease mission risk to an acceptable level, with minimal adverse impact on the agency's resources and mission.

It is significant for staff of banking establishments to comprehend the part of hazard in the financial activities and the dangers that are intrinsic and uncovered in their business tasks. Better comprehension of hazard the executives are additionally fundamental particularly in the budgetary intermediation exercises where overseeing danger is one of the significant exercises. An investigation directed by Boston Consulting Group (2001) found that the sole deciding achievement elements isn't the specialized improvement yet the capacity to comprehend chance deliberately and furthermore the capacity to deal with and control chance hierarchically. Besides, so as to understand a hazard based administration reasoning, the frame of mind and mentality of the representatives should be changed whereby they should be brought to comprehend that overseeing danger is vital for progress. This infers there must be concentrated preparing, plainly characterized structures and duties, just as duty to change. What's more, it was recognized that banks in North America and Australia focus on hazard the executives fundamentally to upgrade their aggressive positions. In the interim in Europe, Asia and especially in South America, hazard the executives is viewed as essential from the point of view of administrative prerequisites. At that point, Al-Tamimi and Al-Mazrooei (2007) found that the UAE banks staffs have great comprehension of risk and the executives, which may give a sign about the capacity of these banks to oversee chances proficiently later on. In addition, getting danger and hazard the board had constructive outcome on risk the executives practice in spite of the fact that it is unimportant.

\subsubsection{Risk Monitoring}

When deciding the technique for risk moderation the client surveys the exhibition, timetable, and cost effects of one relief procedure over another. For something like "parallel" advancement relief, the legislature decides if the expense could dramatically increase, while time probably won't be stretched out by much. For directing fast prototyping or changing operational prerequisites can utilize learning in making models and utilizing prototyping and testing for anticipating the expense and time to lead a model to help moderate specific dangers (e.g., 
necessities). Actualizing all the more building surveys and uncommon oversight and testing may expect changes to authoritative understandings. Frameworks specialists can enable the legislature to evaluate these (timetable and cost) by deciding the premise of appraisals for extra contractual worker endeavors and giving a rude awakening to these assessments.

Monitoring results show that the fundamental issue causing unsuitable risk is non-satisfaction of structure specialized conditions. Additionally, executing the cause-effect and recognizing the underlying cause of risk, the potential risks can be limited or eliminated. The risks can have single or different causes and single or numerous effects. These interdependencies can be basic to recognizing the genuine effect of dangers, and subsequently the money saving advantage examination connected to their relief. For the probabilistic evaluating of risk, we consider a joined arrangement of occasions that reason misfortunes and afterward we decide the likelihood of misfortunes. The information sources and yields for the Risk Monitoring and Control procedure are components from couple of reviews. These incorporate the risk management plan and risk register together with undertaking execution reports and data picked up from the task work itself. As the undertaking continues, a few risks are acknowledged; others have reduced or are never again a risk, while others require further relief movement. The risk register, the organization's processes and the task management plan are refreshed with these progressions throughout the venture. At times, risk moderation and counteractive action require change controls, as do remedial activities for dangers that are figured it out. A good monitoring process helps ensure that control activities and other planned actions to affect internal controls are carried out properly and in a timely manner sufficient to ensure that the end result is effective internal controls. On-going monitoring activities should include various management and supervisory activities which evaluate and improve the design, execution, and effectiveness of internal controls. Periodic monitoring activities, such as self-assessments by various departments and internal audit appraisals, also provide helpful information.

\subsubsection{Internal Control}

Risk is the probability that an event or action will antagonistically influence the organization. The essential classifications of risk are mistakes, oversights, deferral and misrepresentation. So as to accomplish objectives and targets, the executives needs to adequately adjust risk and controls. In this way, control methodology should be grown with the goal that they lessening risk to a level where the executives can acknowledge the introduction to that hazard. By playing out this exercise in careful control "sensible confirmation" can be achieved. The control condition establishes the pace for the association and impacts how representatives lead their exercises and do their control obligations. The control condition is the establishment for every single other segment of inner control and gives structure and order. Building up a solid culture of control cognizance inside the institution is one of the most practical and proficient ways that inner authority over monetary revealing can be actualized. Its impact can pervade all through the Institution, legitimately affecting every one of different parts of inward control. Among the significant variables are the demeanor, mindfulness, and activities of the board and chiefs concerning inward control. The individual qualities, reasoning, and working style of individuals from the executives can impact the association's duty to dependable money related revealing. Since organizations and their work force persistently change, it is basic that controls be checked after some time to decide if they keep on being important and can deliver new risk to the institution. Checking is a procedure that evaluates the nature of an association's interior authority after some time and includes surveying the structure and activity of controls on a convenient premise and accepting activities as important. Observing exercises can likewise uncover proof or side effects of misrepresentation. There are various reasons that an inner control framework may change after some time. The way wherein controls are put in activity may change. This might be on the grounds that controls are connected diversely as control procedures keep on advancing, or controls that were beforehand compelling may never again be performed, or just may not be successful. Among the reasons that control methods may never again be viable are changes in faculty, less viable preparing or supervision, impediments on schedule or assets, or different weights. Likewise, the risk and conditions that control methodology were intended to address may change, which would affect control adequacy. Control activities are those actions that are taken to address risks that threaten the entity's ability to achieve its objectives, one of which is reliable financial reporting. Control activities are usually supported by (1) a policy that established what should be done, and (2) the procedure that implements the policy.

\subsection{Financial Performance}

Financial performance is the accomplishment of the organization's prosperity for a specific period covering the accumulation and portion of money estimated by capital ampleness, liquidity, dissolvability, effectiveness, influence and productivity. The organization's capacity to oversee and control its own asset can be the premise of data for corporate administrators to decide. It is critical to comprehend key examination and specialized investigation, it is important to learn money to comprehend the organization's monetary conduct through financial aspects, budgetary administration and bookkeeping. Money related execution chiefly reflects business segment results and results that show generally monetary wellbeing of the area over a particular timeframe. It demonstrates 
that how well an element is using its assets to boost the investor's riches and productivity. Albeit complete assessments of a company's money related execution consider numerous other distinctive sorts of measures however most normal execution estimation utilized in the field of account and factual induction is monetary proportions. This paper gives a far reaching investigation of the financial exhibition writing concerning the bond business of Pakistan. The writing spread examinations from the Iran, India and Pakistan however some universal confirmations are likewise displayed. The monetary proportions utilized for the estimation of budgetary execution of the concrete division are gainfulness proportions, resource use proportions, influence proportions, liquidity proportions and money transformation cycle from the period 2006-2014. Rate of profitability (ROI) is taken as anticipated variable and five proportion parameters are taken as indicator factors. The examination concentrate found that all parameters have positive association with the needy variable aside from the influence proportions which has irrelevant relationship. This outcome is likewise bolstered by Selvam et al. (2004), though Chandrasekaran (1989) and Dhanalakshmi (1994) distinguished that the outer funds is the key critical factor in deciding interest in bond industry.

Performance with respect to enterprise management is seen as the ability of managing a firm well and the value and its efforts in satisfying its stakeholders (Moullin, 2003). Akande (2011) views performance as the desire to evaluate the extent of success a firm has achieved be it a large or a small firm. Businesses can be evaluated on the basis of its size, number of employees, working capital as well as profitability. There are measures used to evaluate the performance of a business. Some used objective performance measures of Return on Equity (ROE), sales growth and Return on Asset (Shariff, Peou, \& Ali, 2010). Minai and Lucky (2011) suggested performance measures of financial and non-financial approaches to measuring SMEs performance. Financial means include market share, level of debtors and ROA. Non-performance measures also include employee commitment and satisfaction, customer satisfaction and loyalty and minimal customer complaints help create sustainable shareholders value (Cumby \& Conrod, 2001).

In the case of Ittner and Larcker (2003) who were of the view that subjective measures help owner/managers to establish the extent of success or otherwise of their respective SMEs. One can therefore say that, the performance of firms is crucial issues in business activities which entail ample planning as well as commitment. Trkman and McCormack (2009) were of the view that when the organization evaluates their level of performance, it will help them to know if they are progressing or not. For SMEs and large companies, the financial dimension is very important because it on the financial success of the effort that will help them to embark on other critical aspect of payment of salaries and expansion of their business can be implemented (Argument, 1997).

\subsection{Risk Management Practice and Financial Performance}

According to Dixon et al. (1990), appropriate performance measures are those which enable organization to direct their actions towards achieving their strategic objectives. Kotey, Ashelby \& Reid (2002) contends that, performance is measured by either subjective or objective criteria, arguments for subjective measures include difficulties with collecting qualitative performance data from small firms and with reliability of such data arising from different accounting methods used by firms. In this current study, the financial performance was measured and assessed from two main financial ratios namely return on asset (ROA) and return on equity (ROE). Ratio analysis is a form or manner that is commonly used in analysing the financial statements of a company. By using tools such as ratio analysis will be able to explain or illustrate the analyzer about the good and bad circumstances or financial position of a company. An assessment of the financial performance of the company through the financial ratio analysis to obtain a description of the financial development of the company, so we can assess what has been achieved in the past and in the future is running. In this study to measure the company's financial performance, earnings growth is used, because profit is as a tool to measure the performance of the company, which provides information relating to the management responsibilities in the management of the resources entrusted to them (Munawir, 2007). 
Conceptual framework

The study was built on the conceptual framework below:

\begin{tabular}{|l|l|}
\hline RISK MANAGEMENT PRACTICES: \\
i. Risk Management Environment and Policies \\
ii. Risk Measurement
\end{tabular}$\quad \begin{array}{r}\text { FINANCIAL PERFORMANCE: } \\
\text { ROA } \\
\text { iii. Risk Mitigation } \\
\text { iv. Risk Monitoring } \\
\text { v. Internal Control }\end{array}$

\subsubsection{Risk Management Practices and Return on Assets (ROA)}

According Prastowo (2002), Return on Assets (ROA) is utilized to gauge the viability of the organization in producing benefits by abusing its advantages. This proportion may give a sign of positive or negative neighbor management in executing cost control or the board of his property. Profit for Assets (ROA) is regularly utilized as an apparatus to quantify the pace of profit for all out resources after intrigue cost and expenses, (Brigham, 2001). The exceptional yield on Assets (ROA) will be useful for the organization. Worth Return on Assets (ROA) high would show that the organization can produce benefits moderately high esteem resources. Financial specialists might want the organization to the estimation of Return on Assets (ROA) is high, as organizations with Return on Assets (ROA) which is equipped for creating large amounts of corporate benefits is more prominent than the Return on Assets (ROA) is low (Ang, 2001). Profit for Assets (ROA) is a budgetary proportion used to gauge how much the advantages have been utilized to produce benefits. The more prominent Return on Assets (ROA) demonstrates that the better the organization's presentation, in view of the more noteworthy pace of degree of profitability (Riyanto, 2001). As indicated by Harahap (2002), the benefit of an organization's capacity to create income for a specific period. The higher this ratio implies the organization is increasingly compelling in using the resources for produce total compensation. Subsequently the higher ROA implies the organization's presentation increasingly powerful on the grounds that. The pace of return will be more noteworthy. This will further expand the organization's appeal to financial specialists. Expanded appeal of the organization causes the organization progressively sought after by financial specialists since it can give extraordinary advantages (return) for speculators. At the end of the day, ROA will affect stock returns that will be acknowledged by speculators.

In the analysis of financial statement, this ratio is regularly featured, in light of the fact that it can show organization accomplishment to make benefits. ROA can gauge the organization capacity to create benefits in the past to then be anticipated later on. Resources being referred to are generally speaking organization properties, got from the capital itself or from remote capital that has been changed over into organization resources utilized for corporate supportability. Higher ROA value indicates better company performance, because of higher return on investment rate. "This value reflects the company's return on all assets (or funding) provided to the company" (Wild et al, 2005). Any factors affecting on Return on Assets are (a). Liquidity Ratio is a ratio to measure a company's ability to meet its short-term liabilities, calculated by comparing its current assets with current liabilities (b). Asset Management Ratio is "The asset management ratio; measures how effectively the company manages its assets" (Brigham and Houston, 2001). (c). Debt Management Ratio is asset management ratio to know the extent of company's ability to meet its long-term obligations (debt) used to finance all company activities. Company financial performance is one of the factors that can be seen by prospective investors to determine their stock investment. Financial report issued by a company is a reflection of company financial performance. Therefore, this study hypothesized that;

$H_{l a}$ : There is a significant relationship between risk management environment, policies and procedures and return on assets (ROA)

$H_{l b}$ : There is a significant relationship between risk measurement and return on assets (ROA)

$H_{l c}$ : There is a significant relationship between risk mitigation and return on assets (ROA)

$H_{l d}$ : There is a significant relationship between risk monitoring and return on assets (ROA)

$H_{l e}$ : There is a significant relationship between internal control and return on assets (ROA)

\subsubsection{Risk Management Practices and Return on Equity}

Lyn and Aileen (2008) state that return on equity is a measure of return earned by ordinary shareholders. This ratio is also calculated as a return on the equity of a common stock if a company has preferred stock outstanding. The higher ROE is an indication for shareholders that the return on investment rate is higher. According Lestari and Sugiharto (2007) ROE rate can be said well if greater than $12 \%$. Return on Equity (ROE) shows the extent to which companies manage their own capital (net worth) effectively, measure the profitability of the investment that has been made owners of their own capital or shareholders of the company. Ang (2001) which states that the higher the ratio Return on Equity (ROE) will increase the profit growth. Return on Equity (ROE) indicates the profitability 
of own capital or often referred to as business profitability (Sawir, 2005).

The higher the value the higher the ROE level of profit generated due to additional working capital can be used to finance the company's operations that could ultimately result in profit, (Suwarno, 2004). Irawan (2011) in his research found that the results of the Return On Equity (ROE) effect on profit growth This is due to the nature and pattern of investments made by the company are very precise so that all assets can be used efficiently so that profits be maximized. In addition to the revenue generated by capital from debt can be used to cover the cost of capital thus, the higher the ROE, the more compelling the exhibition of an organization and this proportion is likewise used to gauge the capacity of possess money to produce benefits for all investors, both common stock, and preferred stock. An expansion in the organization's stock cost will give an exceptional yield to financial specialists. This will further build the engaging quality of the organization for speculators. This expansion in appeal makes the organization progressively alluring to financial specialists in light of the fact that the pace of return will be more prominent. As known, shareholders has residual claim on obtained profits. Profit obtained by the company firstly will be used to pay any interest of debts, then preference share, and then (if any) will be given to common shareholders. Return on equity (ROE) is the profitability ratio to measure the ability of the company to generate profit based on share capital owned by the company. Therefore, this study hypothesized the following:

$H_{2 a}$ : There is a significant relationship between risk management environment, policies and procedures and return on equity ( $R O E$ )

$H_{2 b}$ : There is a significant relationship between risk measurement and return on equity (ROE)

$H_{2 c}$ : There is a significant relationship between risk mitigation and return on equity (ROE)

$H_{2 d}$ : There is a significant relationship between risk monitoring and return on equity (ROE)

$H_{2 e}$ : There is a strong positive relationship between internal control and return on equity (ROE)

\subsection{Research methodology}

This study employed descriptive design. The selection of descriptive quantitative design was that the researchers wanted to gain a detailed understanding of credit risk management practices of Credit Unions. The target population comprised the credit unions in Kumasi Metropolis. Agyemang, Wingard and Acheampong (2019) referred to population as the total group of items, individuals, objects or events showing common characteristics. The respondents were Credit Risk Management, the Branch Manager and Board Representative, and any Decision maker in the organization. A sample size of 100 was used. A purposive sampling technique was used in the choice of the 100 respondents for the study. The purposive sampling technique was most appropriate because, the researchers were in need of the most appropriate persons who have in-depth knowledge of risk management practices and financial performance of the Credit Union. This study employed self-administered structured questionnaire to collect primary information from participants and respondents in the field. Questionnaire was designed specifically for this study. The study analyzed the quantitative data with the use of Software Package for the Social Sciences (SPSS). In order to be able to select the appropriate method of analysis, the level of measurement must be understood. Ordinal scale is a ranking or a rating data that normally uses integers in ascending or descending order. The numbers assigned to the important $(1,2,3,4,5)$ do not indicate that the interval between scales are equal, nor do they indicate absolute quantities. It utilized descriptive statistics in data presentation and analysis of results. Descriptive statistics tools including frequency distribution tables and descriptive statistics tables were used extensively in this regard. Multiple Regression was used to test the hypotheses. Multiple Regression is the multiple correlation coefficients, R2, which is the proportion of the variance in the dependent variable explained uniquely or jointly by the independent variables.

Reliability is assessed by determining the proportion of systematic variation in a scale, which is done by determining the association between scores obtained from different administrations of the scale (Mazzocchi, 2008). Scale reliability refers to the extent to which a scale can reproduce the same measurement results in repeated trials while random error produces inconsistency in scale measurements, which leads to lower scale reliability (Hair et al., 2003). Reliability analysis was conducted using Cronbach's alpha coefficient for internal consistency.

\subsection{Discussion of results}

4.2 Risk Management Practices in Credit Unions

In endeavors to survey the risk management practices in the credit unions by utilizing the descriptive tests, the study utilized a 5-Likert scale approach in the poll. Risk Management practices are shrouded in five sections: Risk Management Environment, Policies and Procedures, Risk Measurement Practices, Risk Mitigation Practices, Risk Monitoring Practices and Internal Control Practices as recommended by the Basel Committee on Banking Supervision (2001)

Table 4.2: Risk Management Environment, Policies and Procedures

\begin{tabular}{|c|c|c|c|c|c|c|c|}
\hline Items & $\begin{array}{c}\text { SD } \\
(\%)\end{array}$ & $\begin{array}{c}\mathrm{D} \\
(\%)\end{array}$ & $\begin{array}{c}\mathrm{N} \\
(\%)\end{array}$ & $\begin{array}{c}\text { A } \\
(\%)\end{array}$ & $\begin{array}{c}\text { SA } \\
(\%)\end{array}$ & $\begin{array}{c}\text { Mean } \\
\text { Std. } \\
\text { Dev }\end{array}$ \\
\hline 1. A formal risk management system is in place & 0 & 0 & 0 & 62 & 38 & 4.3802 & 0.51134 \\
\hline
\end{tabular}




\begin{tabular}{|ll|c|c|c|c|c|c|c|}
\hline 2. & $\begin{array}{l}\text { Board of directors outlines the overall } \\
\text { objectives }\end{array}$ & 0 & 0 & 23 & 49 & 28 & 3.8812 & 0.63218 \\
\hline 3. & Overall objectives are communicated & 0 & 0 & 0 & 100 & 0 & 4.0000 & 0.00000 \\
\hline 4. & Board of directors approves the overall policies & 0 & 0 & 0 & 16 & 84 & 4.8912 & 0.41276 \\
\hline $\begin{array}{l}\text { 5. } \\
\text { takes necessary actions }\end{array}$ & 0 & 0 & 0 & 20 & 80 & 4.2002 & 0.47701 \\
\hline 6. & The bank adopted and utilised guidelines & 0 & 0 & 0 & 20 & 80 & 4.2000 & 0.47701 \\
\hline 7. & $\begin{array}{l}\text { The bank has the policy of diversifying } \\
\text { investment across different sectors }\end{array}$ & 0 & 0 & 0 & 60 & 40 & 4.4000 & 0.54802 \\
\hline 8. & $\begin{array}{l}\text { The bank has the policy of investment across } \\
\text { different countries }\end{array}$ & 0 & 0 & 63 & 17 & 20 & 3.5823 & 0.89876 \\
\hline
\end{tabular}

Source: Fieldwork (2019)

Note: $\mathbf{S D}=$ Strongly Disagree, $\mathbf{D}=$ Disagree, $\mathbf{N}=$ Neutral, $\mathbf{A}=$ Agree, $\mathbf{S A}=$ Strongly Agree

Risk management environment, policies and procedures are designed to influence and determine all major decisions and actions and all activities take place within the boundaries set by them. They are specific methods employed to express the day to day operations of the organization. Risk management environment, policies and procedures ensure that a point of view held by the governing body of an organization is translated into steps that result in an outcome compatible with that view. They ensure compliance with the law and regulations by means of directing guidance for decision-making and streamlining internal processes.

Concerning "Risk Management Environment, Policies and Procedures", the outcomes as in Table 2 demonstrate that every one of the respondents concurs with item 3: Overall objectives are communicated (with a mean of 4.0000 and 0.00000 standard deviation), showing the significance of straightforwardness in powerful chance administration rehearses. Dominant part of the respondents $(80 \%)$ unequivocally concurred with three items, to be specific item 4: Board of directors approves the overall policies; item 6: The bank adopted and utilised guidelines; and item 5: Board of directors ensures that management takes necessary actions. This indicates a strong agreement amongst the respondents on the importance of the board of directors in the selected credit unions as part of the corporate governance structure. Dynamic interest of the governing body in the risk management practices guarantees consistency in accomplishing the destinations of the banks among the stakeholders.

Table 2 additionally delineates that the least mean is for item 8: The bank has the policy of investment across different countries, which implies that the respondents don't apparent or are not clear if the selected credit unions abiding to a particular guideline in investing across different countries. This could be ascribed to the idea of activities of the majority of the credit unions being chosen in this study, which are particularly depending on the domestic market. Thus, the variety in responses were constituent as majority of the respondents agree to the various questions being asked, so basically risk management environment, policies and procedures have influence of financial performance.

Table 4.3: Risk Measurement

\begin{tabular}{|l|c|c|c|c|c|c|c|}
\hline \multicolumn{1}{|c|}{ Items } & $\begin{array}{c}\text { SD } \\
(\%)\end{array}$ & $\begin{array}{c}\mathrm{D} \\
(\%)\end{array}$ & $\begin{array}{c}\mathrm{N} \\
(\%)\end{array}$ & $\begin{array}{c}\mathrm{A} \\
(\%)\end{array}$ & $\begin{array}{c}\text { SA } \\
(\%)\end{array}$ & $\begin{array}{c}\text { Mean } \\
\text { Std. } \\
\text { Dev }\end{array}$ \\
\hline $\begin{array}{l}\text { 1. A computerized support system for estimating } \\
\text { the variability of earnings and risk management } \\
\text { is in place }\end{array}$ & 0 & 13 & 55 & 12 & 20 & 3.3802 & 0.94134 \\
\hline $\begin{array}{l}\text { 2. } \\
\begin{array}{l}\text { The bank regularly conducts simulation analysis } \\
\text { and measure benchmark (interest) rate risk } \\
\text { sensitivity }\end{array}\end{array}$ & 0 & 0 & 18 & 40 & 42 & 4.4691 & 0.78364 \\
\hline $\begin{array}{l}\text { The bank regularly assessed the positions of } \\
\text { profit and loss }\end{array}$ & 0 & 0 & 0 & 30 & 70 & 4.7691 & 0.61860 \\
\hline $\begin{array}{l}\text { The bank has a quantitative support system for } \\
\text { assessing customers' credit standing }\end{array}$ & 0 & 0 & 0 & 67 & 33 & 4.6847 & 0.63783 \\
\hline
\end{tabular}

Source: Fieldwork (2019)

Note: $\mathbf{S D}=$ Strongly Disagree, $\mathbf{D}=$ Disagree, $\mathbf{N}=$ Neutral, $\mathbf{A}=$ Agree, $\mathbf{S A}=$ Strongly Agree

Proceeding onward to the risk measurement practices, as appeared in Table 3, 80\% of the respondents strongly agreed that the bank consistently assesses the position of profit and loss account (item 3), with high mean of 4.80000 and standard deviation of 0.44702). This will help the bank in dealing with the dangers and uncertainties productively. The most reduced mean is for item 1: A computerized support system for estimating the variability of earnings and risk management is in place (mean of 3.4 and an exclusive requirement deviation of 0.894). This demonstrates that there is as yet deficient automated emotionally supportive network for risk management in the selected credit unions in Kumasi.

Table 4.4: Risk Mitigation 


\begin{tabular}{|c|c|c|c|c|c|c|c|}
\hline Items & $\begin{array}{l}\text { SD } \\
(\%)\end{array}$ & $\begin{array}{c}D \\
(\%)\end{array}$ & $\begin{array}{c}\mathrm{N} \\
(\%)\end{array}$ & $\begin{array}{l}\mathrm{A} \\
\%)\end{array}$ & $\begin{array}{l}\mathrm{SA} \\
\%)\end{array}$ & Mean & $\begin{array}{l}\text { Std. } \\
\text { Dev }\end{array}$ \\
\hline 1. There are credit limits for individual counterparty & 0 & 0 & 0 & 20 & 80 & 4.8002 & 0.44701 \\
\hline 2. The bank regularly reappraises collateral (assets) & 0 & 0 & 18 & 60 & 42 & 4.1871 & 0.71836 \\
\hline $\begin{array}{l}\text { 3. The bank regularly confirms a guarantor's intention to } \\
\text { guarantee their financing with a signed document }\end{array}$ & 0 & 0 & 0 & 73 & 27 & 4.2716 & 0.68032 \\
\hline $\begin{array}{l}\text { 4. The bank has a reserve that can be used to increase the } \\
\text { profit share (rate and return) of depositors and } \\
\text { investment accountholders in low performing period }\end{array}$ & 0 & 0 & 0 & 67 & 33 & 4.6847 & 0.63783 \\
\hline
\end{tabular}

Source: Fieldwork (2019)

Note: $\mathrm{SD}=$ Strongly Disagree, $\mathrm{D}=$ Disagree, $\mathrm{N}=$ Neutral, $\mathrm{A}=$ Agree, $\mathrm{SA}=$ Strongly Agree

Table 4 shows the observation on risk mitigation in the selected credit unions in Kumasi. For risk mitigation practices, $80 \%$ of the respondents emphatically strongly agreed with item 1 : There are credit limits for individual counterparty with a high mean of 4.8002 and standard deviation of 0.44701 .

As appeared in Table 5, for the risk monitoring practices, the most astounding mean of 4.8 is for item 2: The bank regularly (e.g. weekly) compiles a maturity ladder chart according to settlement date and monitor cash position gap. This demonstrates how investors see that the bank has a decent checking framework for the dangers. Table 4.5: Risk Monitoring

\begin{tabular}{|l|c|c|c|c|c|c|c|}
\hline \multicolumn{1}{|c|}{ Items } & $\begin{array}{c}\text { SD } \\
(\%)\end{array}$ & $\begin{array}{c}\mathrm{D} \\
(\%)\end{array}$ & $\begin{array}{c}\mathrm{N} \\
(\%)\end{array}$ & $\begin{array}{c}\mathrm{A} \\
(\%)\end{array}$ & $\begin{array}{c}\text { SA } \\
(\%)\end{array}$ & Mean & $\begin{array}{c}\text { Std. } \\
\text { Dev }\end{array}$ \\
\hline $\begin{array}{l}\text { 1. } \\
\text { The credit limits for individual counterparty is } \\
\text { strongly monitored }\end{array}$ & 0 & 0 & 0 & 50 & 50 & 4.5002 & 0.42629 \\
\hline $\begin{array}{l}\text { The bank regularly (e.g. weekly) compiles a maturity } \\
\text { ladder chart according to settlement and monitor cash } \\
\text { position gap }\end{array}$ & 0 & 0 & 18 & 20 & 82 & 4.8002 & 0.44701 \\
\hline $\begin{array}{l}\text { The bank has in place a regular reporting system } \\
\text { regarding risk management for senior officers and } \\
\text { management }\end{array}$ & 0 & 0 & 0 & 60 & 40 & 4.4001 & 0.54803 \\
\hline $\begin{array}{l}\text { The bank regularly reviews country ratings if their } \\
\text { financial or investments are international }\end{array}$ & 0 & 0 & 0 & 60 & 40 & 4.4001 & 0.54803 \\
\hline $\begin{array}{l}\text { The bank regularly monitors the customer's business } \\
\text { performance after the extension of their financing }\end{array}$ & 0 & 0 & 0 & 40 & 60 & 4.6013 & 0.54803 \\
\hline
\end{tabular}

Source: Fieldwork (2019)

Note: SD = Strongly Disagree, $\mathbf{D}=$ Disagree, $\mathbf{N}=$ Neutral, $\mathbf{A}=$ Agree, $\mathbf{S A}=$ Strongly Agree 
Table 4.6: Internal Control

\begin{tabular}{|l|c|c|c|c|c|c|c|}
\hline \multicolumn{1}{|c|}{ Items } & $\begin{array}{c}\text { SD } \\
(\%)\end{array}$ & $\begin{array}{c}\mathrm{D} \\
(\%)\end{array}$ & $\begin{array}{c}\mathrm{N} \\
(\%)\end{array}$ & $\begin{array}{c}\mathrm{A} \\
(\%)\end{array}$ & $\begin{array}{c}\text { SA } \\
(\%)\end{array}$ & $\begin{array}{c}\text { Mean } \\
\text { Std. } \\
\text { Dev }\end{array}$ \\
\hline $\begin{array}{l}\text { The bank has put in place an internal control system } \\
\text { capable of swiftly dealing with newly recognized } \\
\text { risks arising from changes in environment }\end{array}$ & 0 & 0 & 0 & 100 & 0 & 4.0000 & 0.0000 \\
\hline $\begin{array}{l}\text { There is a separation of duties between those who } \\
\text { generates risks and those who manage and control } \\
\text { risks }\end{array}$ & 0 & 0 & 20 & 20 & 60 & 4.4001 & 0.89401 \\
\hline $\begin{array}{l}\text { The bank has countermeasures (contingency plan) } \\
\text { against disaster and actions }\end{array}$ & 0 & 0 & 0 & 60 & 40 & 4.4001 & 0.54803 \\
\hline $\begin{array}{l}\text { The internal auditor is responsible to review and } \\
\text { verify the risk management systems, guidelines and } \\
\text { risks report }\end{array}$ & 0 & 0 & 40 & 20 & 40 & 4.4001 & 1.00031 \\
\hline 5. The bank has backups of software and data files & 0 & 0 & 0 & 40 & 60 & 4.6013 & 0.54803 \\
\hline
\end{tabular}

Source: Fieldwork (2019)

Note: $\mathbf{S D}=$ Strongly Disagree, $\mathbf{D}=$ Disagree, $\mathbf{N}=$ Neutral, $\mathbf{A}=$ Agree, $\mathbf{S A}=$ Strongly Agree

As per Table 6, for internal control practices, the respondents strongly agreed that "The bank has backups of software and data files" (item 5) with $60 \%$ of the respondents chose "strongly agree". Internal control demonstrates how management of risk can be improved by means of identifying proper measures to combat dangers associated with risk management practices.

\subsection{Financial Performance of the selected Credit Unions}

The study additionally assesses the financial performance of the selected credit unions in Kumasi during the time of 2014-2016 by using selected financial ratios. The financial ratios analysis gives a technique to evaluating the financial qualities and shortcomings of the firm utilizing data found in its fiscal report (Rosly \& Abubakar, 2003). The financial ratios utilized in this study include the rate of return on assets (ROA) and the rate of return on equity (ROE). ROA is the most comprehensive accounting measure of a bank's overall performance. Since it is defined as the net income over total assets, it show the profit earned per cedi of the asset. It is an indicator of bank's efficiency and a measure of the bank's ability to earn rent from its total operations. The ROE, then again, reflects how effectively a bank management is using the shareholder's investment. It tells the bank's shareholders how much the institution is earning on the book value of their investment (Goudreau, 2002).

Table 4.7: Financial Indicators of the selected Credit Unions

\begin{tabular}{|l|c|c|}
\hline \multicolumn{1}{|c|}{ Name of the Union } & Return of Asset (ROA) & Return on Equity (ROE) \\
\hline St. Gabriel's Co-operative Credit Union & 0.40 & 27.59 \\
\hline Presbyterian Credit Union & 0.56 & 8.27 \\
\hline Suame Circuit Co-operative Credit Union & 0.35 & 87.58 \\
\hline St. Martin De Porres Credit Union & 0.82 & 39.35 \\
\hline St. Joseph De-Worker Credit Union & 1.17 & 17.02 \\
\hline
\end{tabular}

Source: Fieldwork (2019)

As shown in Table 4, with reference to the profitability ratios of the selected credit unions, the tables review that St. Joseph De-worker credit union has the highest Return on Asset (ROA) among all the credit unions that were being considered for this study at 1.17 percent, followed by St. Martin De-Porres credit union at 0.8 percent, Presbyterian credit union at 0.6 percent, St. Gabriel co-operative credit union at 0.4 percent and lastly Suame circuit co-operative credit union. However, return on equity (ROE) gives a different perspective being compared to (ROA). Based on the return on equity (ROE), Suame Circuit Co-operative Credit Union has the highest average ROE at 87.6 percent which is largely attributed to the exceptional high ROE in 2015. Nonetheless, St. Martin Deporres Credit Union was next with 39.4 percent ROE compared to the industry average at 58.4 percent in 2015 and 47.3 percent in 2016. St. Gabriel's Co-operative Credit Union followed with 27.6 percent ROE whereas Presbyterian credit union had 8.3 percent return on equity (ROE). From observations, the financial ratios of the selected credit unions for the past three years can help execute the purpose of achieving our research objective.

\subsection{Correlation Matrix}

Correlation is a bivariate analysis that measures the strength of association between two variables and the direction of the relationship. In terms of the strength of relationship, the value of the correlation coefficient varies between +1 and -1 . A value of \pm 1 indicates a perfect degree of association between the two variables. As the correlation coefficient value goes towards 0 , the relationship between the two variables will be weaker.

Table 8 on the other hand presents the results of the correlational analysis. There is a correlation relationship 
between risk management environment, policies and procedures and return on asset (ROA) showing a positive correlation of 0.612. Again, it showed that there is negative correlation between risk measurement and return on asset (ROA). The correlation statistic of -0.096 significant at $1 \%$ indicates that the credit unions measure the risk at which these practices can pose. Furthermore, the correlation outcome indicates that there is negative relationship between risk monitoring and return on asset (ROA). A correlation score of $-0.247(\mathrm{p}<.01)$ was obtained. This designates that any substantial enhancement in the risk monitoring is related to a substantial improvement in financial performance.

Table 8: Correlation Matrix

\begin{tabular}{|c|c|c|c|c|c|c|c|}
\hline & 1 & 2 & 3 & 4 & 5 & 6 & 7 \\
\hline Risk Mgt, Envt, Policies and Procedures & 1 & $\begin{array}{r}-.291^{* *} \\
.000\end{array}$ & $\begin{array}{r}-.003 \\
.960\end{array}$ & $\begin{array}{r}.343^{* *} \\
.000\end{array}$ & $\begin{array}{r}-.088 \\
.161\end{array}$ & $\begin{array}{c}.612^{* *} \\
.000\end{array}$ & $\begin{array}{r}.397^{* *} \\
.001\end{array}$ \\
\hline Risk Measurement & & 1 & $\begin{array}{r}-.032 \\
.612 \\
\end{array}$ & $\begin{array}{r}-.102 \\
.104 \\
\end{array}$ & $\begin{array}{l}.038 \\
.549 \\
\end{array}$ & $\begin{array}{r}-.096^{* *} \\
.000 \\
\end{array}$ & $\begin{array}{r}.425^{* *} \\
.000 \\
\end{array}$ \\
\hline Risk Mitigation & & & 1 & $\begin{array}{l}.030 \\
.633 \\
\end{array}$ & $\begin{array}{l}.038 \\
.542 \\
\end{array}$ & $\begin{array}{r}.764^{* *} \\
.004\end{array}$ & $\begin{array}{r}-.368^{* *} \\
.001\end{array}$ \\
\hline Risk Monitoring & & & & 1 & $\begin{array}{r}-.109 \\
.083\end{array}$ & $\begin{array}{r}-.247^{* *} \\
.000\end{array}$ & $\begin{array}{r}.647^{* *} \\
.002 \\
\end{array}$ \\
\hline Internal Control & & & & & 1 & $\begin{array}{c}.728^{* *} \\
.000\end{array}$ & $\begin{array}{r}.493^{* *} \\
.000\end{array}$ \\
\hline Return on Asset (ROA) & & & & & & 1 & $\begin{array}{r}.543^{* *} \\
000\end{array}$ \\
\hline Return on Equity (ROE) & & & & & & & 1 \\
\hline
\end{tabular}

Source: Fieldwork (2019)

Note: ${ }^{*} \mathrm{p}<.05$ (2-tailed test); ${ }^{* *} \mathrm{p}<.01$ ( 2 -tailed test)

Pertaining to the risk mitigation and return on asset (ROA), the result indicates that there is a positive correlation between the two. The correlation statistic of $0.764(\mathrm{p}<.01)$ signifies that as vulnerabilities increases, risk or uncertainty also heightens accordingly, thus, companies are exposed to undue risks and have to improve corresponding mitigation capabilities. However, overinvestment in such capabilities may erode profits thereby affecting financial performance; hence the credit unions have to find the zone of balanced resilience where their portfolio of capabilities is matched to their pattern of vulnerabilities. In reference to internal control, a correlation statistic of $0.728(\mathrm{p}<.01)$ was obtained showing a positive correlation between internal control and return on asset (ROA). This signifies that when the selected credit unions are able to control their internal systems very well it pave way for those companies to have their return on the book value of their asset.

On the other hand, there is also a correlation between risk management environment, policies and procedure and return on equity (ROE) showing a correlation statistic of $0.397(\mathrm{p}<.01)$. Shareholders are much more cautious about the policies and procedures when managing risk because it is their worth that is been used to assessed all operational work. Again, the table showed that there is a positive correlation between risk measurement and return of equity (ROE) showing a correlation statistic of $0.425(\mathrm{p}<.01)$. Thus measurement of risk has a stronger effect on owners' equity because it is equal to the company's asset minus its debt. Moreover, there is a negative correlation between risk mitigation and return on equity (ROE) showing a correlation statistic of $-0.368(\mathrm{p}<.01)$ which implies that large improvement projects provide an opportunity for profitable investments, then the return on that investment must be protected through active management of the inherent risks. Furthermore, the correlation analysis again showed that there is a correlation between risk monitoring and return on equity (ROE) with a correlation statistic of $0.647(\mathrm{p}<.01)$ meaning the expected return from a given investment with the risk accompanies more elevated amounts of return are required to make up for expanded degrees of risk which reflects the higher the risk undertaken, the more ample the return, and conversely, the lower the risk, the more modest the return. Lastly, there is also a positive correlation between the internal control and return on equity (ROE) with a correlation statistic of $0.543(\mathrm{p}<.01)$ meaning the foundation of long term performance is the attribution of internal controls which provide reasonable assurance regarding the achievement financial compliance.

\subsection{Regression Analysis}

The Hierarchical Multiple Regression (HMR) technique was used to explore the effect of the risk management practices on financial performance using selected financial ratios. The analysis of the regression comprises two interconnected models in which variables were hierarchically included in the estimation. The details of the two 
models are given as follows: Model 1 focused on exploring the direct effects of the risk management practices on return on asset (ROA). Model 2 then examines the effect of risk management practices on return on equity (ROE). All the interactive terms were constructed based on center values of cost risk management practices and financial performance variables as applied in the empirical literature. The fitness of the models is examined using Fstatistics, R-square and variance inflator factors (VIF). The results of the regression analysis are presented on Table 9 and 10.

Table 9 captures the hierarchical linear regression results specifying the effect of risk management practices on selected financial ratio (ROA and ROE). Again, the estimation involved the analysis of two interconnected models; upon which is used to draw conclusions on the study. From model 1 the risk management practices were analysed and tested to see their effect on return on asset (ROA). From the table below, there is a positive relationship between risk management environment, policies and procedures and return on asset (ROA) showing a $(\beta=0.498, p<0.05)$ meaning proper policies and procedures influence an organization's return on asset. Again, there is a positive relationship between risk measurement and return on asset (ROA) showing a $(\beta=0.633, \mathrm{p}<$ 0.10) which signifies that proper measurement of credit unions normally influence the return on their asset. Basically this can be attributed to the users with projections of schedule adjustments needed to reduce risk associated with technology.

Table 4.9 Hierarchical Linear Regression Results - Return on Asset (ROA) Model

\begin{tabular}{|c|c|c|c|c|c|c|}
\hline & Model 1 & & & & & \\
\hline & Beta & $\mathrm{R}^{2}$ & Adjusted $\mathrm{R}^{2}$ & F-statistics & P-value & VIF \\
\hline -Risk Mgt Env. Policies & $.498(0.367)$ & .314 & .310 & 33.873 & 0.020 & 1.53 \\
\hline -Risk Measurement & $.633(0.564)$ & .585 & .581 & 38.865 & 0.102 & 1.49 \\
\hline -Risk Mitigation & $.733(0.591)$ & .746 & .741 & 43.213 & 0.014 & 1.42 \\
\hline -Risk Monitoring & $.861(0.618)$ & .474 & .470 & 36.784 & 0.000 & 1.96 \\
\hline -Internal Control & $.664(0.693)$ & .662 & .658 & 41.412 & 0.012 & 1.34 \\
\hline
\end{tabular}

Note: $\mathrm{t}$-values are in the parenthesis; ${ }^{*} \mathrm{p}<.10 ;{ }^{* *} \mathrm{p}<.05 ;{ }^{* * *} \mathrm{p}<.01$

Table 4.10 Hierarchical Linear Regression Results - Return on Equity (ROE) Model

\begin{tabular}{lllllll}
\hline & \multicolumn{1}{l}{ Model 2 } & \multicolumn{1}{l}{} \\
\cline { 2 - 7 } & \multicolumn{1}{l}{ Beta } & $\mathrm{R}^{2}$ & Adjusted R & F-statistics & P-value & VIF \\
\cline { 2 - 7 } -Risk Mgt Env. Policies & $.781(0.531)$ & .399 & .395 & 42.934 & 0.001 & 1.32 \\
-Risk Measurement & $.323(0.422)$ & .408 & .404 & 44.319 & 0.042 & 1.19 \\
-Risk Mitigation & $.517(0.461)$ & .552 & .548 & 44.213 & 0.105 & 1.56 \\
-Risk Monitoring & $.442(0.231)$ & .717 & .713 & 36.784 & 0.037 & 1.61 \\
-Internal Control & $.395(0.337)$ & .698 & .694 & 41.412 & 0.000 & 1.72
\end{tabular}

Note: $\mathrm{t}$-values are in the parenthesis; ${ }^{*} \mathrm{p}<.10 ;{ }^{* *} \mathrm{p}<.05 ;{ }^{* * *} \mathrm{p}<.01$

Moreover, there is a positive relationship between risk mitigation and return on asset (ROA) showing a $(\beta=$ $0.733, \mathrm{p}<0.01)$ which means adoption of an evolution strategy, identifying and understanding risks will influence the organization's financial performance. Furthermore, the table shows that there is a strong positive relationship between risk monitoring and return on asset (ROA) showing a $(\beta=0.861, p<0.05)$ and lastly there is a positive relationship between internal control and return on asset (ROA) showing a $(\beta=0.664, p<0.01)$ which means taking effective risk management requires a reporting and reviewing of structures to ensure that risks are effectively identified and assessed and that appropriate controls and responses are in place.

Table 10 present the model 2 analysis of the regression table and from the table above, there is a positive relationship between risk management environment, policies and procedures and return on equity (ROE) showing a $(\beta=0.781, \mathrm{p}<0.01)$. Again, there is a positive relationship between risk measurement and return on equity (ROE) showing a $(\beta=1.323, \mathrm{p}<0.05)$ which means that corrective measures put across by the credit unions influence the owner's equity. Moreover, there is a strong positive relationship between risk mitigation and return on equity (ROE) showing a $(\beta=0.517, \mathrm{p}<0.10)$. On this, risks can be characterized as impacting traditional cost, schedule, and performance parameters. Risks should also be characterized as impact to mission performance resulting from reduced technical performance or capability which influences owner's equity. Furthermore, there is a positive relationship between risk monitoring and return on equity (ROE) showing $(\beta=0.442, p<0.05)$ and there is also a positive relationship between internal control and return on equity (ROE) showing $(\beta=0.359, \mathrm{p}<$ 0.01). This implies that there is a consequence of not taking risk, some of it which may be negative and the potential consequences of being overly timid and not taking certain risks hinders financial performance thus, risks are not defeats, but simply bumps in the road that need to be anticipated and dealt with 


\subsection{Hypothesis Testing and Discussion of Results}

Based on the results of the regression analysis, it can be surmised that the pursuit of risk management practices augment the financial performance of the selected credit unions. Thus hypothesis 1 which states risk management practices has a positive relationship with return on asset (ROE); however the level of impact is mixed. Based on this, all the statement under hypothesis 1 which states that risk management practices variables such as risk management environment, policies and procedures, risk measurement, risk mitigation, risk monitoring and internal control have a positive influence on the return of asset (ROA) of the credit unions and the statement is supported. Naroini (2008) investigated the risk management practices and financial performance; and found that risk management practices have a partial positive influence on financial performance. They concluded that risk management practice show the importance of board of directors to approve the overall policies and to ensure that management takes necessary actions to manage the risks. In addition, the findings also show that overall objectives are communicated throughout the bank. The findings of this current study reveal that risk management practice is likely to enhance financial performance of the selected credit unions

Furthermore, generally it was shown that risk management practice is positively related to return on equity and this makes all the statement under hypothesis 2 also true which states that, there is a positive relationship between risk management practice variables such as risk management environment, policies and procedures, risk measurement, risk mitigation, risk monitoring and internal control and return on equity (ROE). Based on this, hypothesis 2 statements are also supported which is consistent with the findings of the empirical studies of Naroini (2008) and Kassim (2008).

Table 4.11 Hypotheses Test Results

\begin{tabular}{|c|l|c|}
\hline Hypotheses & \multicolumn{1}{|c|}{ Statement } & Comment \\
\hline $\mathrm{H}_{1 \mathrm{a}}$ & $\begin{array}{l}\text { There is a significant relationship between risk management environment, policies } \\
\text { and procedures and return on asset (ROA) }\end{array}$ & Supported \\
\hline $\mathrm{H}_{1 \mathrm{~b}}$ & $\begin{array}{l}\text { There is a significant relationship between risk measurement and return on asset } \\
\text { (ROA)) }\end{array}$ & Supported \\
\hline $\mathrm{H}_{1 \mathrm{c}}$ & $\begin{array}{l}\text { There is a significant relationship between risk mitigation and return on asset } \\
\text { (ROA) }\end{array}$ & Supported \\
\hline $\mathrm{H}_{1 \mathrm{~d}}$ & $\begin{array}{l}\text { There is a significant relationship between risk monitoring and return on asset } \\
\text { (ROA) }\end{array}$ & Supported \\
\hline $\mathrm{H}_{1 \mathrm{e}}$ & $\begin{array}{l}\text { There is a significant relationship between internal control and return on asset } \\
\text { (ROA) }\end{array}$ & Supported \\
\hline $\mathrm{H}_{2 \mathrm{a}}$ & $\begin{array}{l}\text { There is a significant relationship between risk management environment, policies } \\
\text { and procedures and return on equity (ROE) }\end{array}$ & Supported \\
\hline $\mathrm{H}_{2 \mathrm{~b}}$ & $\begin{array}{l}\text { There is a significant relationship between risk measurement and return on equity } \\
\text { (ROE) }\end{array}$ & Supported \\
\hline $\mathrm{H}_{2 \mathrm{c}}$ & $\begin{array}{l}\text { There is a significant relationship between risk mitigation and return on equity } \\
\text { (ROE) }\end{array}$ & Supported \\
\hline $\mathrm{H}_{2 \mathrm{~d}}$ & $\begin{array}{l}\text { There is a significant relationship between risk monitoring and return on equity } \\
\text { (ROE) }\end{array}$ & Supported \\
\hline $\mathrm{H}_{2 \mathrm{e}}$ & $\begin{array}{l}\text { There is a significant relationship between internal control and return on equity } \\
\text { (ROE) }\end{array}$ & Supported \\
\hline
\end{tabular}

Source: Field Study (2019)

\subsection{Conclusion}

The purpose of this study is to impact of risk management practice and financial performance of some selected credit unions in Kumasi. The study revealed a strong positive relationship between all the risk management practices variables such as risk management environment, policies and procedures, risk measurement, risk mitigation, risk monitoring and internal control and financial performance variable such as return on asset (ROA) and return on equity (ROE). It was found out that majority of the respondent's strongly agree that risk management practices put in place can enhance financial performance of the firm.

\subsection{Recommendation}

Anchoring on the study findings, the researcher finds it imperative to make few recommendations and recommend areas for further research on the subject matter of impact of project management practices on financial performance. The following recommendations were therefore made in reference to the study area

$>$ Remaining in control is a relative concept in a largely unpredictable world as well as there are no riskfree organizations or error-free managers. When presenting strategies and plans, senior management 
should recognize that the future is inherently uncertain ant that its endless possibilities are too complex for anyone to predict with great accuracy. Instead of maintaining the illusion that the future can be fully understood or controlled, senior management should show courage and honesty when updating key stakeholders based on the latest forecasts.

$>$ The organization's culture will benefit from clarity on what is expected from managers and staff employees. Clear communication regarding what constitutes acceptable behavior and what doesn't, as well as the bandwidths of acceptable deviations from stated objectives that risk tolerance must be provided. The board should initiate open discussions about the level of internal control required to manage key stakeholders' expectations, and senior management should encourage learning from the company errors rather than simply tearing down those responsible. Above all, senior management and the board should lead by example, a prerequisite for effective risk management.

$>$ Furthermore, senior management should treat risk management (dealing with events that could happen) and incident management (dealing with events that have happened) in concert. They should ask questions such as "How well trained is our organization to handle serious incidents when they occur?" and "How well established is our continuous improvement cycle?" They should also convince the business managers that a proactive, integrated approach for both risks and incidents is needed to keep the business control framework fit for purpose.

\section{REFERENCES}

Agyemang, J. K., Wingard, C. H., \& Acheampong, O. (2019). Fair Value Accounting in the Agricultural Sector: The Analysis of Economic and Educational Factors. Asian Journal of Economics, Business and Accounting, 9(4), 1-13.

Akkizidis, I. \& Khandelwal, S.K. (2008), "Financial Risk Management for Islamic Banking and Finance” Palgrave Macmillan, First Edition.

Al-Tamimi, H. \& Al-Mazrooei M. (2007), "Banks' risk management: a comparison study of UAE national and foreign banks", The Journal of Risk Finance, Vol. 8, No.4, pp. 394-409.

Angbazo, L. (1997), "Commercial Bank Net Interest Margins, Default Risk, Interest Rate Risk, and Off-Balance Sheet Banking”, Journal of Banking and Finance, Vol. 21, pp. 55-87.

Ariff, M. and Can, L. 2007, "Cost and profit efficiency of Chinese banks: A non-parametric analysis" China Economic Review.

Aziz, Z. A. (2006). Extending the Boundaries in the New Financial Landscape. Governor of Bank Negara's Speech at the 10th Malaysian Banking, Finance and Insurance Summit: Liberalization and Consolidation of Malaysian Banking and Finance Sector: Enhancing Competitiveness and Resilience of Our Economy, Kuala Lumpur, June 9.

Bashir, A.H. (2000). Determinants of Profitability and Rate of Return Margins in Islamic Banks: Some Evidence from the Middle East, Presented at the ERF's Seventh Annual Conference, October 26-29, Amman, Jordan.

Berger, A.N., Hunter, W., and Timme, S. (1993). "The Efficiency of Financial Institutions: A Review and Preview of Research: Past, Present, and Future”, Journal of Banking and Finance, Vol. 17, pp. 221-49.

Berger, A.N. (1995). The Relationship between Capital and Earnings in Banking, Journal of Money, Credit, and Banking, Vol. 27, No. 2.

Berger, A.N., Richard, J.H., and Giorgio P. S. (1995). The role of capital in financial institutions, Journal of Banking and Finance, Vol. 19, pp. 393-430.

Berger, A.N. \& Mester, L.J. (1997). Inside the black box: What explains differences in the efficiencies of financial institutions?, Journal of Banking and Finance, Vol. 21, No. 7, pp. 895-947.

Berger, A.N. and Humphrey, D.B. (2000). Efficiency of Financial Institutions: International Survey and Directions for Future Research in Harker, P.T. and Zenios, S.A. (2000). Performance of Financial Institutions: Efficiency, Innovation, Regulation" Cambridge University Press.

Berger, A. N., DeYoung, R., Flannery, M. J., Lee, D. K. and Oztekin, O. (2008). How Do Large Banking Organizations Manage Their Capital Ratios? Available at SSRN: http://ssrn.com/abstract=1098928.

Bodnar, G.M., Hayt, G.S. and Marston, R.C. (1996). Wharton Survey of Derivatives Usage by U.S. Non-Financial Firms", Financial Management, Vol. 25, No. 4, pp.113-133.

Bodnar, G. M., Gregory S. H. and Richard, M. C. (1998). What not Survey of Financial Risk Management by Non-Financial Firms, Financial Management, Vol. 27, Winter, pp.70-91.

Brewer, E., Jackson, W.E. and Moser, J.T. (1996). Alligators in the Swamp: The Impact of Derivatives on the Financial Performance of Depository Institutions", Journal of Money, Credit, and Banking, Vol. 28, pp. 482497.

Cai, Z. and Wheale, P. (2007). The New Capital Accord and the Chinese Banking Industry", Journal of Banking Regulation, Vol. 8, No. 3, pp. 262-289.

Darrat, A. F., Topuz, C., and Yousef, T. (2002), Assessing Cost and Technical Efficiency of Banks in Kuwit Paper 
Presentation to the ERF's 8th Annual Conference in Cairo, January 2002.

Dermirguc, K.A., and Huizinga, H. (1999). Determinants of Commercial Bank Interest Margins and Profitability: Some International Evidence, World Bank Economic Review, Vol. 13, No. 2, pp. 379-408.

Diamond, D.W., and Rajan, R. G. (1999). A Theory of Bank Capital Working Paper, University of Chicago.

Dionne, G., Cummins, J. D., Gagne, D. and Abdelhakim, N. (2007). Efficiency of Insurance Firms with Endogenous Risk Management and Financial Intermediation Activities, Available at SSRN: http://ssrn.com/abstract=900384.

Dolde, W. (1993). The Trajectory of Corporate Financial Risk Management, Journal of Applied Corporate Finance, Vol. 6, No. 3, pp. 33-41.

Drzik, J. (2005). New Directions in Risk Management, Journal of Financial Econometrics, Vol. 1, pp. 26-38.

Fathiyah, H. (2006). Capital Structure and Performance of Islamic banks and IBS Commercial Banks in Malaysia Presented at the National Seminar on Islamic Banking and Finance, KUIM, 29-30 August 2006.

Fenn, W., Post, M. and Sharpe, S. (1997). Does Corporate Risk Management Create Shareholder Value? A Survey of Economic Theory and Evidence, in "Financial Risk and the Corporate Treasury: New Development in Strategy and Control", London, Risk Publication, pp. 13-31.

Freeland, C. and Friedman, S. (2007). Risk and the Need for Capital in Archer, Simon and Karim, R. A. A. (2007) "Islamic Finance: The Regulatory Challenge", John Wiley \& Son (Asia) Pte Ltd.

Froot, K.A., Scharfstein, D.S., and Stein, J.C. (1993). Risk Management: Coordinating Corporate Investment and Financing Policies, Journal of Finance, Vol. XLVIII, No. 5, 1993, pp. 1629-1658.

Gallati, R. (2003), Risk Management and Capital Adequacy", McGraw-Hill.

Gennotte, G. and Pyle, D. (1991). Capital Controls and bank risk, Journal of Banking and Finance, Vol. 14, Issue 4-5, pp. 805-824.

Girardone, C., Molyneux, P. and Gardener, E.P.M. (2004). "Analysing the determinants of bank efficiency: the case of Italian banks", Applied Economics, Vol. 36, No. 3, pp. 215-227.

Glaum, M. and Forschle, G. (2000). Finanzwirtschaftliches Risikomanagement deutscher Industrie- und Handelsunternehmen- Industriestudie, PwC Deutsche Revisio Aktiengesellschaft (editors) Frankfurt am Main: Fachverlag Moderne Wirtschaft.

Grais, W., and Kulathunga, A. (2007). Capital Structure and Risk in Islamic Financial Services”, in Archer, S. and Karim, R. A. A. (2007) "Islamic Finance: The Regulatory Challenge", John Wiley \& Son (Asia) Pte Ltd.

Grigorian, D. A., and Manole, V. (2002). Determinants of Commercial Bank Performance in Transition: An Application of Data Envelopment Analysis, World Bank Policy Research Working Paper No. 2850. Available at SSRN: http://ssrn.com/abstract=636214.

Hahm, J.H. (2004).; Interest rate and exchange rate exposures of banking institutions in pre-crisis Korea, Applied Economics, Vol. 36, No. 13, pp.1409-19. 